\title{
From Legal Awareness of the Contemporary Youth to Legal Culture of the Information Society
}

\begin{abstract}
The need for law education is indispensable in the individual and, as a consequence, social dimension. Its early initiation will "internalize” patterns of behaviour and response which will contribute to conscious functioning in society, and, as a result, building of a society of law. Therefore, one of the goals of the presented text is to indicate the fact that ignorantia iuris nocet. Such a conceptualization is preventive, prophylactic, and inhibitory. First and foremost, the purpose of addressing the issue is to show the need to raise legal awareness that builds legal culture of society, and improves the quality of life. The analysis of the results of the research conducted among schoolchildren aged 15-16 indicates that legal awareness of the young generation differentiates the frequency of behaviours contrary to social and legal standards - the higher legal awareness of young people is, the lower the level of particular problem behaviours in this group is. The paper also outlines recommendations on solutions that can be used to create future prevention programs aimed at building an aware information society and the high legal culture of its members.
\end{abstract}

Keywords:

law, legal awareness, legal culture, youth, information society

1 Department of Social Pedagogy, Faculty of Pedagogy and Psychology, University of Białystok, Poland, e-MAIL: w.danilewicz@interia.pl.

2 Department of General Pedagogy and Methodology of Pedagogical Research, Faculty of Pedagogy and Psychology, University of Białystok, Poland, E-MAIL: t.prymak@wp.pl. 


\section{INTRODUCTION}

Contemporary man functions in many areas and in dimensions which did not exist in the past and concern increasing variability in human activity, exemplified in the family, occupational and spatial spheres (international migration being an example). The development of new communication technologies - e-mail, social networking, blogosphere, interactive electronic media - is also one of the qualities of the new information society. The use of new technologies requires user knowledge. To cope with intricacies of the ever-changing reality, these new areas entail legal awareness. Particular attention is paid to the young generation whose early law education will contribute to building of legal culture and, as a result, the rule of law. The need for law education is indispensable in the individual and, as a consequence, social dimension. Its early initiation will "internalize” patterns of behaviour and response which will contribute to conscious functioning in society, and, as a result, building of a society of law. Therefore, one of the goals of the presented text is to indicate the fact that ignorantia iuris nocet. Such a conceptualization is preventive, prophylactic, and inhibitory. First and foremost, the purpose of addressing the issue is to show the need to raise legal awareness that builds legal culture of society, and improves the quality of life.

\section{LEGAL AWARENESS AS A CONDITION OF LEGAL CULTURE OF A SOCIETY}

Legal culture is one of the subject areas of culture that can be classified as societal (social) (Gryniuk, 2002). Different types of cultures, depending on a specific sphere, can be distinguished. There is, therefore, a political, economic, religious or legal culture that is part of a global culture (Pieniażek \& Stefaniuk, 2014).

There are many definitions of legal culture, shaped and disseminated in Polish sociology of law. Several concepts of legal culture, including anthropological, behavioural, comparative, systemic, are discerned (Markowska-Gos, 2002). It is emphasized that within the framework of legal culture there are individuals' expectations regarding the law and the judiciary, their legal intuitions and convictions about their rights and obligations, as well as the patterns of conduct with which they exercise their rights and obligations (Kurczewski, 2007).

The behavioural view embraces attitudes and beliefs manifested towards law (Szubert, 1983), or "a group of intertwined attitudes and behaviours - both individual and collective - and their effects on the law, i.e., on all duties, rules and norms imposed, sanctioned and systematically enforced by the authority of 
the relevant community, resulting from the shared system of values” (Russocki, 1986).

Legal culture is generally regarded as a synonym of a legal system, and, thus, as a collective concept, which consists of all norms, institutions, and a system of values and behaviours derived from law (Szafarz, 1997).

In Polish sociology of law, another concept is widespread - the normative concept of legal culture. According to the classical approach, legal norms being part of legal culture meet certain socially accepted conditions; they are disseminated and transmitted by symbols and signs; they are characterized by certain durability, usually associated with tradition and "cultural heritage” (Kojder, Łojko, Staśkiewicz, \& Turska, 1990). Law is an element of culture, and many of behavioural patterns contained included in legal norms were created similarly to other social norms, note the quoted authors (Kojder et al., 1990).

The mentioned examples show that legal culture is a complex concept, comprehensively defined only with both objective and subjective terms, which consists both of "the state of law (its content and form), the doctrine of law and jurisprudence, political institutions involved in law-making and application of law and everything which is part of the concept of legal culture in a narrower sense, i.e., the knowledge of individual and social groups on law in force, their attitude towards that law (readiness or lack of readiness to abide by norms), views on law and postulates concerning its change" (Chauvin, Stawecki, \& Winczorek, 1999).

Legal awareness (aside from moral, political, aesthetic and other) is one of the forms of social awareness, and is therefore part of "a system of values, norms and directives commanding or prohibiting something, containing descriptive and imaginary elements expressed in our knowledge and world outlook" (Faliński, 1999), which subjects are people (individuals) and subject matter - the whole of their knowledge, opinions, ideas, philosophical, political, legal, religious, aesthetic and cultural views (Łopatka, 2000). The subject of legal awareness which is distinguished within the system is, in turn, positive law, which content consists of knowledge about it, the individual's attitude towards it and legal ideology, and its subjects are "people as members of particular social groups or as persons in certain social roles” (Pieniążek \& Stefaniuk, 2014).

The question arises as to the relation between legal awareness and legal culture. Due to the diversity of interpretations on this relation, the opinion of M. Borucka-Arctowa (1981) regarding legal awareness as an intrinsic part of legal culture included in it next to other elements can be adopted as reliable.

Taking into account the complexity of the relationship between legal culture and legal awareness, legal awareness can be defined as "knowledge about law, 
views and attitudes towards existing norms and legal and political institutions, and any postulates concerning existing legislation” (Borucka-Arctowa, 1981). In this interpretation, legal awareness constitutes an inseparable element and one of the basic components of the broadly defined complex phenomenon of "legal culture." On the one hand, legal culture consists of the legal order composed of the system of law in force, divided into the branches of law and, on the other hand, the sense of law, the most important of which is legal awareness, i.e., the whole of knowledge about law, the collection of affective judgments on law, attitudes towards law and postulates of changes to the existing legal system (Pilipiec, 2011).

\section{THE LEGAL AWARENESS OF THE YOUTH AND BEHAVIOURS CONTRARY TO SOCIAL NORMS - THE OUTLINE OF AUTHORS' RESEARCH ${ }^{3}$}

Legal awareness of humans, like its other forms, is shaped by adopting their social experience, a specific system of knowledge and behavioural standards. "The spiritual atmosphere, the legal climate prevailing in the community has a great influence on the individual's assimilation of legal norms. The more stable the legal order of society is, the higher the discipline of its members, the deeper the respect for law and the rule of law, the more effective the process of building legal culture, legal knowledge and legal beliefs. Conversely, the atmosphere of lawlessness, nihilistic attitude to laws, lack of discipline - entail antisocial attitudes, antisocial behavior”, notes Brunon Hołyst (1998), emphasizing the essential connection between legal awareness and the tendency to behave in a manner consistent or incompatible with law - pathological and contrary to the norms of conventional society. At the same time, the author indicates that legal culture (and hence legal awareness) is conditioned by the environment in which from an early age a person is taught to conduct and to choose values to be internalized.

The theoretical basis for the methodological assumptions of the research was, in addition to the already mentioned concept of culture and legal awareness, the theory of problem behaviour by Richard and Shirley Jessor (2001) (which allowed for the categorization of behaviour contrary to social norms), and the concept of resilience. Resilience is often understood as a developmental process by which children acquire the skills to use internal and external resources to achieve good

3 In the paper the Authors use the excerpts from the research results presented in detail in the doctoral dissertation: T. Prymak, Legal awareness of middle school students in Białystok and their problematic behaviour, prepared under scientific supervision of Professor Wioleta Danilewicz. 
adaptation (positive adaptation) despite past or present adversity (Yates, Egeland, \& Sroufe, 2003). These resources are referred to as protective factors. The list of protective/risk factors is not enumerative, and the concept itself provides the basis for further exploration, especially in terms of those factors that contribute to reducing behaviour contrary to social norms and maximizing the protective mechanism of human adaptation. The high level of legal awareness may be such a factor. The occurrence of such a connection can be proved by the results of the study done by Denise C. Gottfredson (1987), where a course on legal and social awareness of adolescents with special risks of committing crime and offenses was conducted. The legal solutions concerned interpersonal relationships, society, family, work and the ability to achieve life goals. One year after the end of the class, improvements in learning performance, greater involvement in school work, and a reduction in the number of criminal behaviours were identified.

\section{THE RESEARCH METHODOLOGY}

The research was conducted in the second quarter of 2014 with 586 third graders from middle schools in Białystok. However, the basis for the selection of the sample was not the stage of education, but the age of the respondents - 15-16-yearolds, and the specificity of the adolescent period in which a particular crisis is embedded - a breakthrough in the current mental development line, when the task is to define themselves as a social beings functioning and cooperating with other people according to accepted or developed norms and models (Oleszkowicz, 1993). The sampling was both nonprobability and random one. Białystok was chosen as the place of the research. The sample was selected in the draw, which took place in two stages (a two-stage draw). The first step was to draw the schools in which the study was to be conducted. The draw was a group that defined one of three levels of middle school. This level was determined on the basis of the average scores of the middle school exam of the year preceding the research (Regional Examinations Board - OKE Data, 2014). Three schools with the highest results, four schools with average results and three schools with the lowest results in the middle school examinations in humanities and mathematics and science parts were randomly selected. The second stage of the draw involved middle school students of all third grade classes present at school on the day of the research conducted in the middle schools.

The diagnostic survey method was used in the research. The research techniques were the survey and scaling, within which the following original research 
tools were constructed: the scale for examining the types and frequencies of problem behaviours of middle school students and the scale for the level of legal awareness of middle school students.

The characteristics of the surveyed population showed that the sample fulfilled the representativeness feature with regard to level of the middle school performance results (estimated on the basis of the results of the middle school examinations in 2013), and also due to the minimum necessary sample size. The group was also heterogeneous, varied with reference to the variables being analyzed, and that also made the validity of the conclusions drawn during the analysis of the results of the research probable.

\section{SELECTED RESEARCH RESULTS}

The analysis and interpretation of the collected empirical material took place in three stages. The first one involved determining the level of legal awareness of the surveyed youth. The research tool The scale for the examination of the level of legal awareness of middle school students was therefore made up of 3 subscales. The respondents' task was to respond to 60 examples concerning knowledge on the four categories of behaviour - crimes, offenses, misbehaviours and acts not sanctioned by law (20 questions), their assessment (20 questions) and the readiness to behave in the indicated manner (20 questions). Each item was assigned points in the range of 1 to 5 points. The further procedure consisted in transforming the raw test results into converted standardized scales, using a stenographic scale. Table 1 presents the general level of legal awareness of middle school students regarding criminal law norms.

The analysis of the empirical data obtained using the applied research tool allows to state that the most numerous group is composed of the respondents with the average level of legal awareness. They represent $43.5 \%$ of the total sample. Every third respondent (32.6\%) represents a low level of knowledge, judgment and disposition related to activities relevant from the perspective of criminal law. On the other hand, the least number of respondents was with the high level of legal awareness. Every fourth respondent belonged to it (23.9\% of the sample).

The second stage of the analysis of the research results aimed at determining the average frequency of particular types of problem behaviours of the youth aged 15-16 years. The study used the typology of R. and S. Jessor, identifying two basic groups of problem behaviours - violent behaviour (including categories of verbal violence, physical violence, economic violence, cyberbullying, and sexual 
Table 1. The level of legal awareness of middle school students

\begin{tabular}{|c|c|c|c|c|c|c|c|}
\hline \multicolumn{8}{|c|}{ The general level of legal awareness } \\
\hline \multicolumn{2}{|c|}{ Low } & \multicolumn{2}{c|}{ Average } & \multicolumn{2}{c|}{ High } & \multicolumn{2}{c|}{ Total } \\
\hline $\mathrm{N}$ & $\%$ & $\mathrm{~N}$ & $\%$ & $\mathrm{~N}$ & $\%$ & $\mathrm{~N}$ & $\%$ \\
\hline 191 & 32.6 & 255 & 43.5 & 140 & 23.9 & 586 & 100 \\
\hline
\end{tabular}

Source: own calculations.

violence), and use of psychoactive substances by middle school students, including narcotic drugs/psychotropic substances (hereinafter referred to as drugs), alcohol, tobacco and pharmaceutical drugs (despite the lack of ailments) use. After conducting the research, the responses (the elements of the continuum) selected by the respondents were assigned point values from 1 to 5 , according to the values: 1 - never (0 times), 2 - rarely (1-2 times), 3 - sometimes (3-4 times), 4 - often (5-10 times), 5 - very often (over 10 times). The introduction of numerical values made it possible to measure and, thus, enabled to calculate the arithmetic means being the generalized frequency indices in the categories within all the distinct types of problem behaviour. In the text, the Authors omit detailed presentation of the average frequency of particular types of problem behaviours, focusing on the results of the third stage of analysis - the recognition of the relationship between legal awareness and the average frequency of the described behaviour.

At the stage of constructing the detailed hypotheses, it is assumed that there is a link between the level of legal awareness of middle school students and the frequency of the three types of behaviour undertaken by this group - violence, use of psychoactive substances (narcotic drugs, psychotropic substances, their substitutes, drinking alcohol, smoking tobacco, pharmaceutical drugs abuse), and unlawful acts and demoralization manifestations. Chart 1 shows the mean frequency of the categories of violence for low, average and high levels of legal awareness.

The analysis of the results of the research presented in Chart 1 shows that the level of legal awareness of middle school students varies the frequency of particular categories of violent behaviour. Individuals representing low levels of legal awareness revealed a higher frequency for each category of violence. Accordingly, persons with the high level of legal awareness declared the lowest frequency of verbal, physical, economic, and sexual violence and cyberbullying. The largest differences between people representing high levels of legal awareness and those with low levels of legal awareness were in the range of the average frequency of physical violence ( $\bar{x}=2.16$ and $\bar{x}=1.41$, respectively). There was a significant scattering between persons representing high and low levels of awareness regard- 


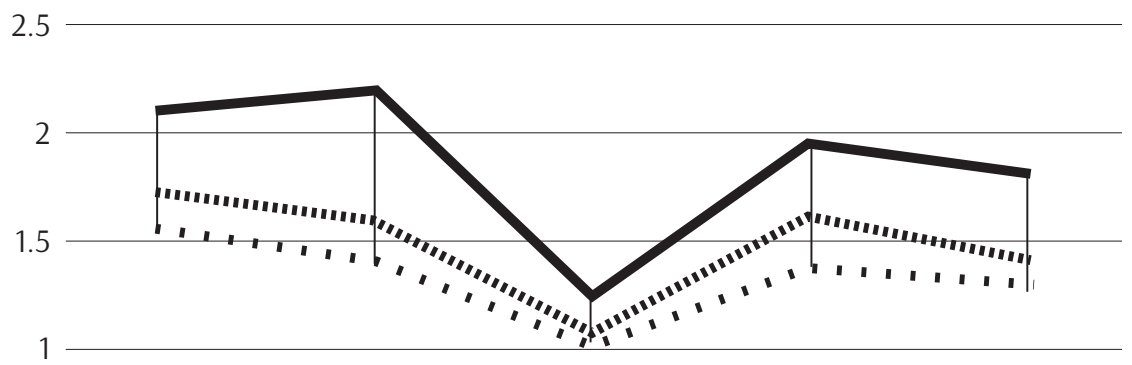

0.5

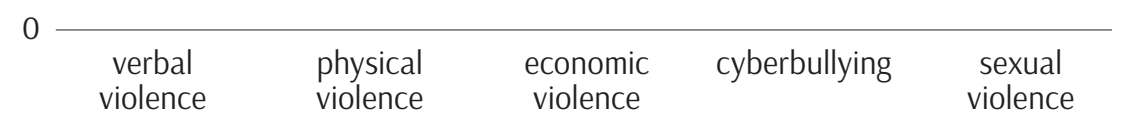

low level of legal awerness

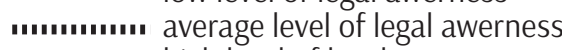

! י י י ' high level of legal awerness

Chart 1. The level of legal awareness of middle school students and the frequency of violent behaviour

Source: own calculations.

ing verbal violence $(\bar{x}=2.09$ and $\bar{x}=1.58$, respectively), cyberbullying $(\bar{x}=1.95$ and $\bar{x}=1.38$, respectively) and sexual violence $(\bar{x}=1.75$ and $\bar{x}=1.25)$. In turn, the smallest differences were indicated in the case of economic violence. In this case, there was a minimal difference between the arithmetic mean of the frequency of violent behaviour against property in the group with the average $(\bar{x}=1.05)$ and low $(\bar{x}=1.03)$ levels of legal awareness.

The research also assumes that there is a link between the level of legal awareness of middle school students and the frequency of use of psychoactive substances. Chart 2 shows the average frequency of each category of this problem behaviour for low, average, and high levels of legal awareness.

The analysis of the data presented in the Chart 2 allows to state that the level of legal awareness of middle school students differentiate the frequency of different categories of the variable concerning use of psychoactive substances. Individuals with low levels of legal awareness revealed a higher frequency for each category of this type of problem behaviour. On the other hand, students representing a high 


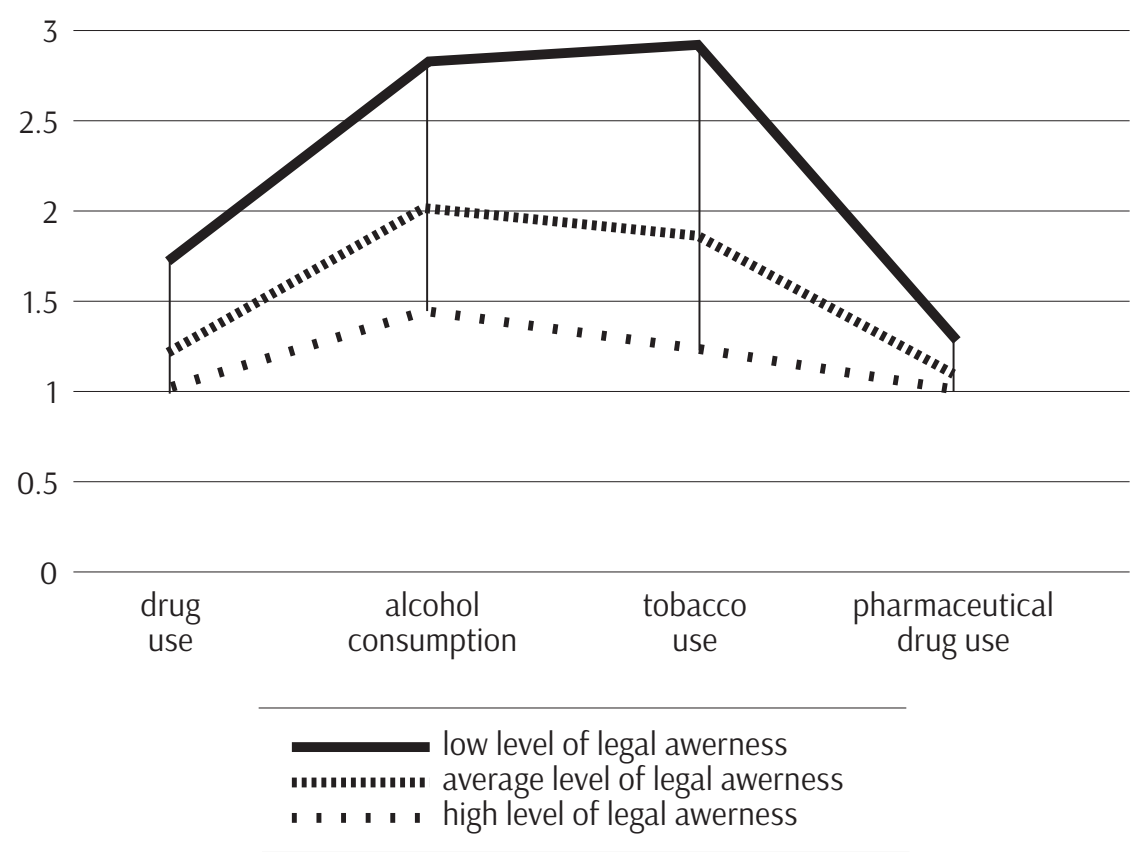

Chart 2. The level of legal awareness of middle school students and the frequency of psychoactive substance use

Source: own calculations.

level of legal awareness declared the lowest frequency of use of any mentioned psychoactive substance, including drugs, alcohol, tobacco, and pharmaceutical drugs. Definitely the largest differences between those with high levels of legal awareness and those with low levels of legal awareness are in the frequency of alcohol use (the arithmetic mean $\bar{x}=2.82$ and $\bar{x}=1.43$, respectively) and tobacco use (respectively $\bar{x}=2.85$ and $\bar{x}=1.29$ ). A significant scattering between individuals representing high and low levels of legal awareness can be observed in the case of problem behaviour which is particularly dangerous from the perspective of the young generation's health - drug use $(\bar{x}=1.72$ and $\bar{x}=1.04$, respectively). The level of legal awareness of middle school students differentiate in the smallest degree with regard to the frequency of pharmaceutical drug abuse, because the difference between individuals representing high and low levels of legal awareness is negligible (the arithmetic means $\bar{x}=1.27$ and $\bar{x}=1.03$, respectively). In each analyzed case, students with the average level of legal awareness also declared the average frequency of use of particular psychoactive substances. 
The Spearman's rank correlation coefficient test (rho Spearman m test) was used to determine the significance of the relationship between the analyzed variables (Table 2).

Table 2. The relationship between the level of legal awareness of middle school students and the frequency of problem behaviours

\begin{tabular}{|c|c|c|c|c|}
\hline Variables & $\begin{array}{c}\text { Type } \\
\text { of problem } \\
\text { behaviours }\end{array}$ & $\begin{array}{c}\text { Category } \\
\text { of problem behaviours }\end{array}$ & $\begin{array}{c}\text { Rho-Spearman's } \\
\text { correlation } \\
\text { coefficient }\end{array}$ & $\begin{array}{c}\text { Correlation } \\
\text { significance } \\
\text { coefficient }\end{array}$ \\
\hline \multirow{9}{*}{$\begin{array}{c}\text { Level } \\
\text { of legal } \\
\text { awareness }\end{array}$} & \multirow{5}{*}{$\begin{array}{l}\text { Violent } \\
\text { behaviour }\end{array}$} & verbal violence & -0.343 & 0.000 \\
\hline & & physical violence & -0.375 & 0.000 \\
\hline & & economic violence & -0.264 & 0.000 \\
\hline & & cyberbullying & -0.270 & 0.000 \\
\hline & & sexual violence & -0.219 & 0.000 \\
\hline & \multirow{4}{*}{$\begin{array}{c}\text { Use of } \\
\text { psychoactive } \\
\text { substances }\end{array}$} & drug use & -0.390 & 0.000 \\
\hline & & alcohol consumption & -0.446 & 0.000 \\
\hline & & tobacco use & -0.405 & 0.000 \\
\hline & & $\begin{array}{c}\text { pharmaceutical drugs } \\
\text { abuse }\end{array}$ & -0.270 & 0.000 \\
\hline
\end{tabular}

Source: own calculations.

The analysis of the results showed that there is a statistically significant relationship between these variables (at the level of $p<0.000$ ) and it is negative - the higher the level of legal awareness of middle school students, the lower the frequency of each violence category included in the research, and inversely - the lower the level of legal awareness among young people, the higher the frequency of particular categories of violence. The strongest relationships relate to verbal violence and physical violence. The significant result of the statistical test confirmed the statistically significant relationship between the level of legal awareness of middle school students and the frequency of psychoactive substances use (at the level of $p<0.000$ ). The higher the level of legal awareness of middle school students, the lower the frequency of use of particular types of psychoactive substances, and vice versa - the lower the level of legal awareness among young people, the higher the frequency of particular categories of the other variable. These interdependencies are recognized for each category of substances, and they are the strongest for alcohol, tobacco, and drug use. 


\section{DEVELOPING LEGAL AWARENESS AS A CURRENT CHALLENGE OF EDUCATION AND A CONDITION OF LEGAL CULTURE OF THE INFORMATION SOCIETY. CONCLUSIONS}

The empirical exploration of the legal awareness of young people has not been elaborated on in the literature so far. However, both the theoretical diagnoses of legal socialization, the results of few studies, and the findings of the research cited in this paper, distinctly demonstrate that there is a clear need for educational actions aimed at increasing legal awareness of this age group.

Nevertheless, the problem of legal norms and the rules of responsibility for breaking them is still placed on the sidelines of school-based tasks, despite many problems embedded in the specifics of adolescence and stemming from the lack of legal knowledge. Young people should be aware that, for instance, throwing a cigarette butt or using vulgarity can be punished with a fine, for drinking alcohol in public places, in addition to a fine, they can stand trial for minors, and for possession of up to half a gram of a drug they can be imprisoned (Kacprzak, 2016). Legal education creates a chance that some will avoid committing crimes in the future. First and foremost, however, it is a chance not only for functioning "without” punishment - but also approaching the social functioning “with” internalized principles and values.

Legal education consists of all sorts of initiatives addressed to different social groups in order to raise legal knowledge and awareness (Woźniakowska-Fajst, 2012). Its educational quality depends on: the functioning framework, i.e., the core curriculum, curricula and materials for classes (including textbooks and scenarios for teachers), preparation of teachers, use of the experience and potential of Polish non-governmental organizations, involvement of lawyers (Woźniakowska-Fajst, 2012). In relation to each of these elements, it should be made clear that the existing legal education in Poland has not been systematically and thoughtfully carried out at any level of education. ${ }^{4}$

The initiatives undertaken in the field of legal education by the so-called third sector - non-governmental organizations, although valuable, are characterized by fragmentary and ad hoc programs such as Street Law, the Youth Rights Advocate and the School Safety Program through legal education. They were a novelty, which remained in the sphere of one-off activities and experiments. The same is true of involvement of professionals in the legal education - lawyers dealing with legal issues on a daily basis. Activities such as teaching law in schools by judges gathered in such associations as "Iustitia" and "Themis" or other initiatives promoted by district councils of legal advisors and individuals, although highly appreciated, are also not conducted in a systematic way and most frequently consist of short-term local projects, which often come to just one meeting of students with legal practitioners. 
Contrary to the previous practice, we believe that systematic legal education should begin in parallel with the onset of children's education. In-depth education in this area aimed at acquainting people with interpersonal relations, social norms, injunctions and prohibitions, as well as consequences for failure to comply with them, should be carried out on all future stages of education. The analysis of the findings of the research unequivocally confirmed that young people possessing legal awareness related to criminal law are less inclined towards breaching norms envisaged by this branch of law.

The introduction of legal education into the core curriculum of schools should not, however, be of a sudden and one-off nature - some elements building legal awareness, among others, familiarizing adolescents with consequences of behaviour contrary to legal standards should be introduced to students already at the elementary and even pre-school level, where the child learns about, among others, the principles of common good. Legal education cannot have the nature of diffused, incidental activities, unconnected at the level of organized learning, and it has to create conditions for what E. Durkheim, M. Weber, T. Parsons, J. Habermas or L. Petrażycki understood as the concept of legal socialization.

It is also worth paying attention to the preparation of teaching staff to conduct legal education. It is necessary for at least two reasons. It provides teachers with educational tools in the form of knowledge of disciplinary measures, but primarily it gives them the opportunity to be an "ambassador" and a creator of legal culture.

The presented analysis of existing standards for the development of legal awareness among the young generation through formal education reveals that, despite some activities aimed at improving the situation, legal education requires immediate, systematic action in all the elements that determine its quality.

\section{References:}

Borucka-Arctowa, M. (1981). Świadomość prawna a planowe zmiany społeczne. Wrocław: Zakład Narodowy im. Ossolińskich.

Chauvin, T., Stawecki, T., \& Winczorek, P. (1999). Wstęp do prawoznawstwa. Warszawa: C.H. Beck.

Faliński, A. (1999). Świadomość społeczna. In: Z. Krawczyk, \& W. Morawski (Eds.), Socjologia. Problemy podstawowe (pp. 260-272). Warszawa: Państwowe Wydawnictwo Naukowe.

Gottfredson, D.C. (1987). An Evaluation of an Organization Development Approach to Reducing School Disorder, Evaluation Review, 11(6), pp. 739-763.

Gryniuk, A. (2002). Kultura prawna a świadomość prawna, Państwo i Prawo, 1, pp. 15-31. 
Hołyst, B. (1998). Świadomość prawna. In: W. Szewczuk (Ed.), Encyklopedia psychologii (pp. 226-331). Warszawa: Fundacja Innowacja.

Jessor, R. (2001). Problem-Behavior Theory - A Brief Overview. Retrieved from: http://www. colorado.edu/ibs/jessor/pb_theory.html

Kacprzak, T. (2016). Świadomość prawna Polaków. Retrieved from: http://www.prawo.akcjasos.pl/content/view/83/9/

Kojder, A., Łojko, E., Staśkiewicz, W., \& Turska, A. (1990). Elementy socjologii prawa. Wybór tekstów, 3. Warszawa: Wydawnictwo Uniwersytetu Warszawskiego.

Kurczewski, J. (2007). Prawem i lewem. Kultura prawna społeczeństwa polskiego po komunizmie, Studia Socjologiczne, 2, pp. 33-60.

Łopatka, A. (2000). Prawoznawstwo. Warszawa: Polskie Wydawnictwo Prawnicze Iuris.

Markowska-Gos, E. (2002). Kultura prawna młodzieży studenckiej. Studium socjologiczno-prawne. Rzeszów: Wydawnictwo Uniwersytetu Rzeszowskiego.

Oleszkowicz, A. (1993). Adolescencja. Wybrane aspekty rozwojowe i wychowawcze. Ujęcia teoretyczne i empiryczne weryfikacje. Wrocław: Wydawnictwo Uniwersytetu Wrocławskiego.

Pieniążek, A., \& Stefaniuk, M. (2014). Socjologia prawa. Zarys wykładu. Kraków: Wolters Kluwer SA.

Pilipiec, S. (2011). Kultura prawna a prawo obywatela do ochrony słusznego interesu, Studia Iuridica Lublinensia, 15, pp. 143-155.

Regional Examinations Board - OKE Data. (2014). Secondary School Exam Guide. Retrieved from: http://www.oke.lomza.pl/index.php?option=com_content\& view=article\&id=613 \&Itemid $=8$

Russocki, S. (1986). Wokół pojęcia kultury prawnej, Przegląd Humanistyczny, 30(11-12), pp. 15-22.

Szafarz, R. (1997). Kultura prawna prawa europejskiego na tle traktatów Rady Europy, Studia Prawnicze, 1, pp. 4-15.

Szubert, W. (1983). Uwagi o kulturze prawnej. In: A. Kłoskowska (Ed.), Naród - Kultura - Osobowość (pp. 569-582). Wrocław: Zakład Narodowy im. Ossolińskich.

Woźniakowska-Fajst, D. (2012). Edukacja prawna - możliwości, szanse, bariery. Warszawa: INPRIS.

Yates, T.M., Egeland, B., \& Sroufe, A. (2003). Rethinking Resilience. A Developmental Process Perspective. In: S.S. Luthar (Ed.), Resilience and Vulnerability: Adaptation in the Context of Childhood Adversities (pp. 245-266). Cambridge: Cambridge University Press. 